International Journal of Biological Research, 2 (2)(2014) $140-142$
International Journal of Biological Research
Journal home page: $\begin{gathered}\text { www.sciencepubco.com/index.php/IJBR } \\ \text { doi: } 10.14419 / \text { ijbr.v2i2.3398 } \\ \text { Research Paper }\end{gathered}$

\title{
Immature paramphistomosis in a sheep herd
}

\author{
S. Sivajothi ${ }^{1 *}$, B. Sudhakara Reddy ${ }^{2}$ \\ ${ }^{1}$ Assistant Professor, Dept. of Veterinary Parasitology \\ ${ }^{2}$ Assistant Professor (Veterinary Medicine), Teaching Veterinary Clinical Complex \\ College of Veterinary Science, Sri Venkateswara Veterinary University, \\ Proddatur - 516360, Y.S.R.District, Andhra Pradesh, India. \\ *Corresponding author E-mail: sivajothi579@gmail.com
}

\begin{abstract}
Paramphistomosis is one of the important endo parasitic diseases of small ruminants and causes considerable economical loss to the farmers. The present communication reports about the outbreak of immature paramphistomosis in a sheep herd in Y.S.R.District of Andhra Pradesh. The disease is characterized by sub maxillary edema and severe persistent fluid foetid diarrhoea. Gross examination of the fluid faeces revealed presence of the whitish pink colour round bodies and later they identified as immature paramphistomes. Affected sheep were treated with niclosamide @ $100 \mathrm{mg} / \mathrm{kg}$ body weight orally once along with supportive therapy.
\end{abstract}

Keywords: Immature Oxyclozanide, Paramphistomosis, Sheep, Y.S.R.District.

\section{Introduction}

Livestock plays an important role in the economy of poor people in India. Domesticated small ruminants, especially sheep and goat are important sources of protein for many countries. Due to improper care, unhygienic environmental conditions, extreme climatic variations and close contact with infected animals; other livestock get infected with a variety of parasites. Paramphistomosis (Amphistomosis) is a disease caused by digenean trematodes belong to the family Paramphistomatidae. Adult paramphistomes are the main parasites in the rumen and reticulum of sheep, goats, cattle and buffaloes. Their early stages are in small intestine and then migrate through the abomasum towards the rumen (Sanabria $\&$ Romero 2008). The harm caused by this infection in bovine affects production, since these parasites provoke a lower nutritious conversion, loss of body weight and decrease in milk production, which cause economic losses (Rolfe et al. 1991). Different reports on adult paramphistomosis was recorded by species wise, month wise and season wise in India and worldwide (Hassan et al. 2005; Kanyari et al. 2009). But, little information was available on occurrence of immature paramphistomosis in India. Hence, present report about the occurrence of immature paramphistomosis in a sheep herd in Y.S.R.District of Andhra Pradesh.

\section{Materials and methods}

This study was conducted in a sheep herd consist of 65 sheep at Yerraguntla, Y.S.R.District of Andhra Pradesh. All the sheep in this herd were belongs to the 2 months to 4 years age, belongs to the both sex. Out of 65 sheep 18 were showing the signs of weakness, anorexia, sub maxillary edema, loss of body condition, copious fluid foetid diarrhoea, thirsty with frequent drinking of water and soiling of hind legs and tail with fluid faeces (Fig.1 and 2).

Up on clinical examination of sheep lowered rectal temperature $\left(100.4 \pm 1.2^{\circ} \mathrm{F}\right)$, raised heart rate $(118 \pm 11 / \mathrm{min})$ with pale colour congenctival mucus membranes and reduction in the body condition were observed. Gross examination of recently voided faecal sample revealed the presence of whitish pink coloured rounded bodies. Microscopic examination of the bodies had prominent anterior and posterior suckers and they are identified as immature paramphistomes (Fig.3). Microscopic examination of faces was done by sedimentation method and did not reveal any parasitic ova.

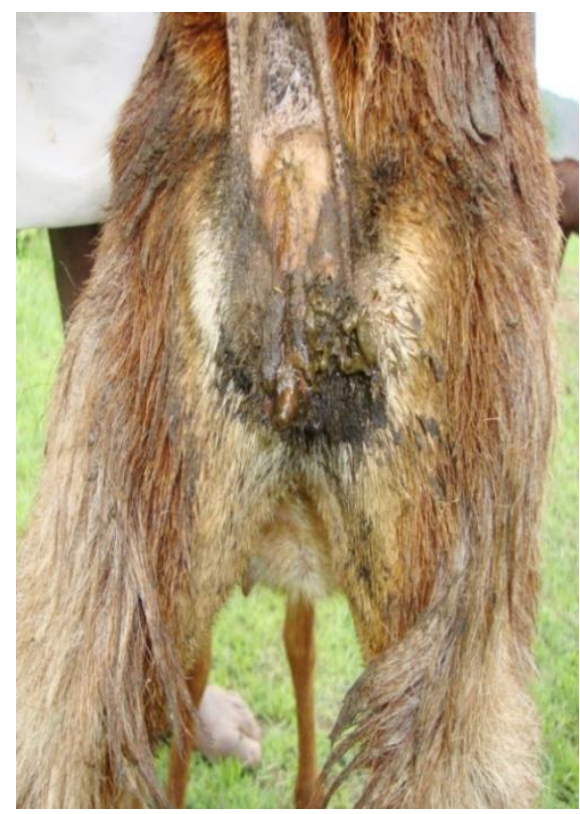

Fig. 1: Sheep suffering with severe fetid diarrhoea and soiling of hind legs. 


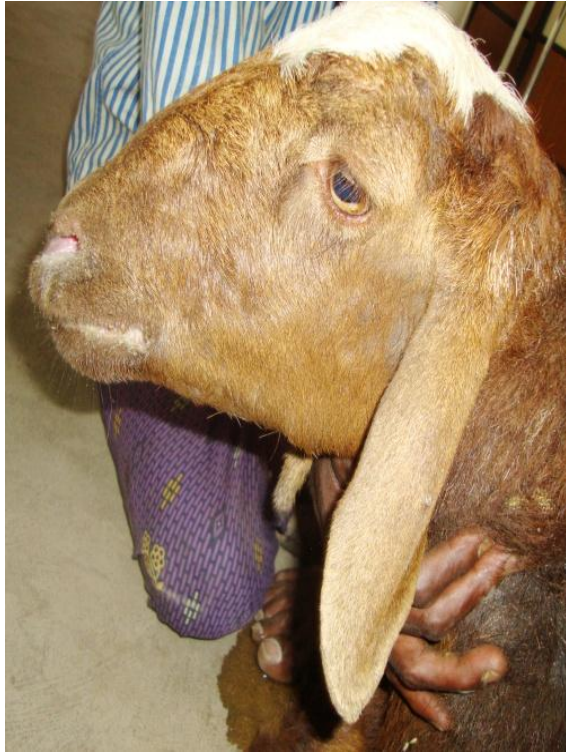

Fig. 2: Sheep showing the sub maxillary edema.

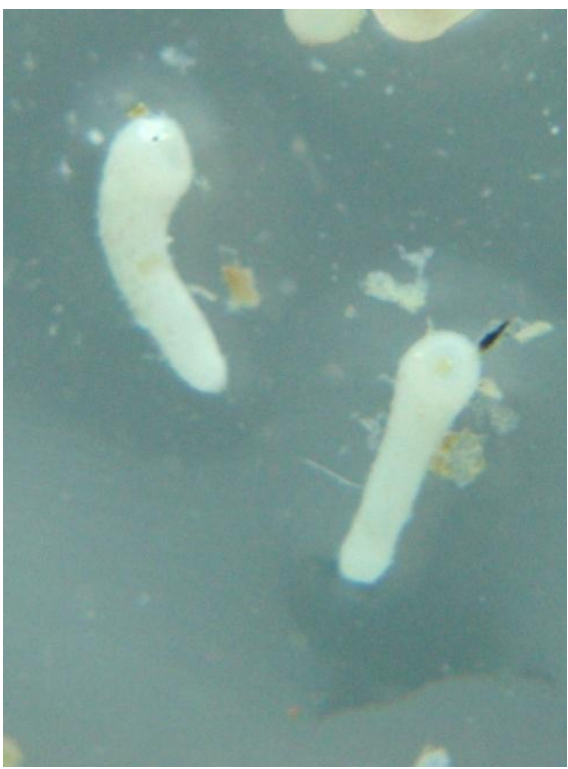

Fig. 3: Immature paramphistomes (100X) in the faecal samples.

\section{Treatment and discussion}

Based on the clinical signs, herd history and laboratory examination of the fluid faeces condition diagnosed as immature paramphistomosis. Sheep were treated with niclosamide @ $100 \mathrm{mg} / \mathrm{kg}$ body weight rally once along with supportive therapy of anti-diarrhoeal powder (Neblon powder @ 10 gms/sheep, PO, daily for 3 days), haematinic preparations (Boli. Feritas@1/3 Boli/ sheep, PO, daily for ten day) and electrolyte powder (ORS powder @ $4.1 \mathrm{gm} / \mathrm{sheep}$, PO, BID for 3 days). After initiation of therapy affected sheep were recovered from the diarrhoea.

Paramphistomum cervi is one of the common parasites in the rumen and reticulum of sheep, goats, cattle and buffaloes. Infection with immature paramphistomes in the small intestines of immunologically incompetent hosts was recorded (Gupta 1993). The immature flukes are responsible for destroying the mucosal walls of the alimentary tract on their way to growing into adults. By the fervent tissue obliteration the clinical symptoms are manifested. The adult flukes, on the other hand are quite harmless, as they merely prepare for reproduction (Brown 2005). The occurrence of paramphistomosis in an area is influence by a multifactoril system that is composed of hosts, parasitic agents, transmission process and environmental effects.
Most of the adult paramphistomes had little pathogenic significance and immature worms cause fatal damage to the cattle and sheep (Foster et al. 2008, Millar et al. 2012). A high number of immature stages of the paramphistomes in the duodenum and upper ileum are responsible for severe pathological changes. These are embedded in the mucosa and are plug feeders, drawing pieces of the mucosa into the suckers which pinch them off causing necrosis and haemorrhage (Soulsby, 2006). Incidence of gastrointestinal helminthes is related to the agro-climatic conditions like quantity and quality of pasture, temperature, humidity and grazing behavior of the host (Pal \& Qayyum 1993).

Moisture and temperature have a critical role in the propagation of infection, because they affect the hatching of fluke ova, viability of encysted metacercariae and population of snails. The high incidence of immature amphistomosis in the sheep farm could be due to grazing of sheep in stagnated water bodies surrounding the pastures. More stagnated water bodies conducive for the preponderance of snail population, which in turns predisposes the release of number of cercariae in to the water and nearby forage.

Due to the irrigation canals, distribution of paramphistomes eggs may occur (Maqbool et al. 2003). Seasonal reproduction in paramphistomes species showed marked seasonality in egg production, with peak activity during the monsoon and post monsoon months (Shanila \& Hafeez 2005, Diaz et al. 2007). In ovine, fatality due to severe haemorrhagic enteritis associated with visible nodules on the mucosal surface duodenum (Mason et al. 2012). Clinical signs noticed in immature paramphistomosis, were because of helminthic parasites adversely affect the absorption and utilization of proteins, minerals and vitamins as well as upset the general metabolism of the host by causing diarrhea, anemia and liver disorders (Anand et al. 2000).

\section{Conclusion}

Immature Paramphistomosis was diagnosed in the sheep herd based on the presence of immature worms in the faecal samples. Report of immature amphistomosis may be due to overstocking of the animals, grazing of young and adult animals together with poorly drained land. This higher incidence of infection may be attributed to lower immunity of hosts as a result of malnutrition.

\section{References}

[1] Anand L, Dhanachand C, Mohilal N, Sharatkumar S (2000) Prevalence of intestinal helminths in dairy cattle of Manipur, Uttar Pradesh Journal of Zoology, 2000, 20:93-95.

[2] Brown DS (2005) Freshwater Snails of Africa and Their Medical Importance (2 Ed.). Taylor \& Francis Ltd. pp., 366-370.

[3] Diaz P, Pedreifra J, Arias M, Sanchez-andrade T, Suarez JL, Arias MS Francisco I, Fernandez G, Diez-banos P, Morrondo P, Paz-silva A (2007) Risk periods of infection by Calicophoron Daubneyi (Digenea: paramphistomidae) In cattle from oceanic climate areas. Parasitol. Parasitology Research, 101, 2:339-342. Doi.org/10.1007/s00436-0070493-z.

[4] Foster AP, Otter A, O'Sullivan T, Cranwell AP, Twomey DF, Millar MF, Taylor MA (2008) Rumen fluke (paramphistomosis) in British cattle, Veterinary Record, 162, 528. Doi.org/10.1136/vr.162.16.528-a

[5] Gupta N (1993) Amphistomes, systematics and biology. New Dehli, India, Oxford and IBH Publishing

[6] Hassan SS, Kaur K, Joshi K, Juyal PD (2005) Epidemiology of paramphistomosis in domestic ruminants in different district of Punjab and other adjoining areas. Journal of Veterinary Parasitology, 19 (1), 43-46.

[7] Kanyari PWN, Kagira JM, Mhoma RJ (2009) Prevalence and intensity of endoparasites in small ruminants kept by farmers in Kisumu Municipality, Kenya. Livestock Research for Rural Development. Volume 21, Article \#202. http://www.lrrd.org/lrrd21/11/kany21202.

[8] Maqbool A, Hayat CS, Tanveer A, Ahmad I (2003) Prevalence and ecology of Lymnaea snails in Punjab. Iranian Journal of Veterinary Research, 4, 2:132.

[9] Mason C, Stevenson H, Cox a, Dick I, Rodger C (2012) Disease associated with immature paramphistome infection in sheep, Veterinary Record, 170, 343-344. Doi.org/10.1136/vr.e2368. 
[10]Millar M, Colloff A, Scholes S (2012) Disease associated with immature paramphistome infection, Veterinary Record, 171, 509510. http://dx.doi.org/10.1136/vr.e7738.

[11]Pal RA, Qayyum M (1993) Prevalence of gastrointestinal nematodes of sheep and goats in upper Punjab, Pakistan, Pakistan Veterinary Journal, 13 (3): 138-141.

[12]Rolfe F, Boray JC, Nichols P, Collins GH (1991) Epidemiology of paramphistomosis in cattle. International Journal for Parasitology, 21:813-819. Doi.org/10.1016/0020-7519 (91)90150-6.

[13]Sanabria REF, Romero JR (2008) Review and update of paramphistomosis Helminthologia, 45 (2): 64 -68. DOI: 10.2478/s11687-008-0012-5. Doi.org/10.2478/s11687-008-0012-5.

[14]Shanila PK, Hafeez M (2005) Prevalence of paramphistomosis in cattle in Chittoor district of Andhra Pradesh, India. Journal of Parasitic Diseases, 29, 1: 10-08.

[15] Soulsby E.J.L., Helminths, arthropods and protozoa of domesticated animals, 7th Ed. Bailliere Tindall, London, 2006, 69-71. 